\title{
Enhancing informed empathy as a key to promoting social justice in religious education classes
}

\author{
Anuleena Kimanen ${ }^{1}$ (D)
}

Accepted: 27 January 2022 / Published online: 14 February 2022

(c) The Author(s) 2022

\begin{abstract}
In the field of education concerning cultural diversity it has been recognized as vital to address justice in social structures. Although justifications for religious education in nonconfessional contexts are heavily based on religious diversity, their advocates have paid little attention to justice and power relations. In this article, I analyse observations of five observed classroom activities on social justice designed for religious education and related pupil interviews. The participants were in the eighth and ninth grades of Finnish comprehensive school. The main question is: how do elements of informed empathy and perception of social justice emerge in interviews and RE classroom activities with Finnish lower secondary school pupils? The results show that the concept of informed empathy well describes the pupils' emerging awareness of social justice, that pupils' critical agency should be carefully fostered and that social justice has potential to make religious education more relevant for certain pupils.
\end{abstract}

Keywords Social justice $\cdot$ Religious education $\cdot$ Empathy $\cdot$ Critical agency $\cdot$ Social justice literacy

\section{Introduction}

Developing intercultural and interfaith understanding is regarded as an important goal of religious education (RE) in state schools in open societies (see e.g. Kimanen \& Kallioniemi, 2018; Sjöborg, 2013). However, the approach to interfaith relationships usually stresses harmony and assumes equality between the parties of interfaith dialogue. Within intercultural education there is a strong tendency to pay attention to power relations (e.gDolby, 2012; Gorski, 2012; May \& Sleeter, 2010). As RE in democratic societies contains goals like responsibility, values, empathy and mutual understanding, there is much potential for social justice. Critical approaches have not yet fully reached theorization within RE.

Concerning RE, issues of justice and participation are addressed in discussions on RE's place in citizenship and moral education. Osbeck et al. (2018) have used Jones's (2009)

Anuleena Kimanen

anuleena.kimanen@helsinki.fi

1 Faculty of Theology, University of Helsinki, Helsinki, Finland 
classification according to which the Swedish ethics education (part of RE) curriculum takes both conservative and liberal approaches: it both seeks to enhance certain values (conservative) and stresses the importance of developing personal standpoints (liberal). This curriculum lacks the critical approach that would identify subordinated groups and aim at social change.

Jones's (2009) classification can be used to describe the twofold character of citizenship education. It is about both nation-building and encouraging active participation for the common good (Arthur et al., 2010; Poulter, 2019). It is grounded, thus, on two concerns, for social cohesion and for societal participation (Jackson, 2003). Nation-building, that is, promoting 'national' values that the pupils cannot choose, can be labelled as conservative in approach. Active participation admittedly encourages personal engagement but the common good is either predefined by the curriculum designers (conservative) or left to the individual preferences of the pupil (liberal) without critical reflection on privilege and power. Predefined goals in RE include peaceful interaction in a religiously diverse society (Miedema \& Bertram-Troost, 2008; Jackson, 2003). Poulter (2019, p. 48) even points out a process of 'personalization of citizenship' that 'has managed to hide the mechanisms of power and state control within the individual': the same values that were formerly politically and religiously defined, are now defined in pluralist and individualist terms. Apart from these concerns, there is no empirical research on the thinly elucidated but highly justified social justice dimension of RE.

This study was conducted within a project that developed material to help teachers in comprehensive schools address cultural diversity in the spirit of critical multicultural education (e.g. May \& Sleeter, 2010). Because the host organization was Faculty of Theology and because the eight class and subject teachers involved in the project were interested in developing RE, many of the designed materials and activities were best suited for RE. Data was collected in order to evaluate the piloted activities, but can be used more generally to analyse the pupils' reactions. This article focuses on the classroom activities, conducted at two similar lower secondary schools (pupils aged 14-16) in privileged urban areas, that aimed at encouraging pupils to think about social justice issues.

This article seeks to find out how ethnic and religious majority pupils from eighth and ninth grades (14 and 15 year-olds) perceived justice issues in RE classes. Dolby's (2012) concept of informed empathy is adopted to outline the pupils' perceptions. Dolby argues that multicultural education should do more than merely provoke compassion towards those who suffer around us or around the globe. It is social change, not charity, that is needed. According to her concept of informed empathy, from a privileged position it is impossible to intuitively know the needs of those who suffer. Sustainable change requires societal change and empowerment of those who are in disadvantaged position. Thus, the research question of this article is as follows: How do elements of informed empathy and perception of social justice emerge in interviews and RE classroom activities with Finnish ethnic and religious majority pupils in lower secondary school?

\subsection{Concepts: informed empathy and social justice literacy}

In this article, I refer to social justice as an orientation towards addressing power imbalances and changing oppressive structures, following the critical or transformative approach within multicultural or intercultural education as opposed to its superficial or conservative forms (Mikander, Zilliacus, \& Holm, 2018; Gorski \& Parekh, 2020). Social justice is not seen as distributive justice, i.e. equal distribution of resources, but 
as entailing recognition that different groups do not profit equally from equal opportunities (Boyles et al., 2008). Social justice education has been suggested as a more sustainable substitute for intercultural education, as it does not restrict itself to culture (Mikander et al. 2018). This study follows Gorski (2012) in recognizing that when addressing equity in any dimension, it is necessary to include several different forms of equity. Working at intersections may also avoid the essentialist tendency to explain people's behaviour by their culture or any single factor. However, as this article is about how a social justice approach could contribute to the theorization and practices of RE, the focus here is on religious diversity. This brings the study closer to critical multicultural education than broader social justice education.

According to Sleeter (1996), in its beginning in the 1960s US, multicultural education was anti-oppressive. Due to political shift and practical obstacles, however, critical approaches were then marginal. Today, critical approaches have a stronghold at least within theorization of multicultural education (see e.g. Mikander et al., 2018). Dolby (2012) is only one of the theorists who use the concept of social justice (for others, see e.g. Sleeter, 1996; Moore, 2008). For Dolby (2012), cultivating informed empathy and widening the moral circle are tools for enabling actions that could lead to social justice. Her underlying idea is to avoid the deficit approach. Even if pupils representing the ethnic or cultural majority are not initially interested in fighting inequalities, cultivating their informed empathy and widening their moral circles enables the educator to work on where they are now. Widening the moral circle, for Dolby, means raising concern about diverse people around the globe, and also for animals and the environment, as humans cannot be detached from that whole.

In her book, Dolby does not provide a concise definition for informed empathy. In the following, theory and research on empathy are used to formulate a working definition. First, cognitive empathy can be defined as the intellectual process of attempting to understand another person's thoughts, feelings or intentions. Research shows that empathy produces constructive behaviour, regardless of the accuracy of the perspective-taking (Davis 2009).

Kasl and Yorks (2016) propose what the 'informed' part could mean by adopting John Heron's types of knowing. According to Heron and Reason (2008), there are four types of knowing. Propositional knowing is the intellectual form of knowing, ideas and theories expressed through language. Experiential knowing is essentially tacit and preverbal. Presentational knowing entails images and narratives manifested, for instance, in diverse forms of art, and practical knowing is about skills and competencies. According to Kasl and Yorks (2016), empathy involves both propositional knowing and experiential knowing, but if the two experiential worlds are very different, the distance between them is best bridged through presentational knowing. Hence, an empathy that is informed would mean knowing in all necessary forms. Even practical knowing can be connected to the definition, because it leads to informed action.

Second, from the social justice perspective, something is missing. In addition to knowing suitable ideas and experiences, one needs an ability to apply key concepts related to justice and power. Following Sensoy and DiAngelo (2017), I call this ability critical social justice literacy. Third, social justice requires 'social actors who have a sense of their own agency as well as a sense of social responsibility toward and with others' (Bell, 2007, p. 1). This kind of agency has been called critical agency and researched in the context of teacher education by Moore (2008) and Francis and LeRoux (2011). Cultivating these abilities in younger pupils has been bypassed in the previous research; they form the frame of analysis for this study. 
Empathy has been addressed in previous research on RE (Kimanen \& Kallioniemi, 2018), but without the critical approach. This article seeks to fill the gap in empirical research on RE by taking a qualitative approach to young people's views. In Finland, RE is taught in separate denominational groups provided that certain conditions are met. Due to demographic factors, Lutheran pupils in Finland represent both the religious and the ethnic majority. Church membership is not required to attend RE classes, so not all the Lutheran RE pupils are Lutheran but, especially in ethnically homogeneous schools, Lutheran RE groups provide a context where enhancing informed empathy is relevant. As Gorski (2012) notes, social justice does not depend on minoritized people's empathizing with the dominant groups, about whose perspectives they are generally well informed. Although analysis of power can inform about both privilege and disadvantage, and this happened in the observed lessons, the power positions of the pupils will be analysed in detail elsewhere. Here the focus is on perceptions of social justice, perspective taking and agency-assuming that due to the context described above, the pupils were fairly evenly privileged.

\subsection{Context: justice in the Finnish curriculum and learning outcomes}

Justice is mentioned in the underlying values and mission of the Finnish Core Curriculum for Comprehensive Education (Finnish National Agency for Education, 2016). As a whole, the curriculum is supposed to build seven transversal competencies. Justice is mentioned in the seventh transversal competency (participation, involvement and building a sustainable future) in grades 1-2. Other concepts that could represent Jones's (2009) critical approach are equality, responsible attitude and sustainable future - at least they extend the approach beyond the conservative and liberal stances.

The RE curriculum in comprehensive education consists of an extensive common core with stated learning goals, proposed teaching methods and content, and more concise denomination-specific parts (e.g. Lutheran, Orthodox, Islamic). The terms justice, equality and equity do not appear in the RE curriculum although they are mentioned in the secular ethics curriculum and in some other subjects. There is little indication of a critical approach. In grades 7-9 critical thinking is mentioned, but directed towards evaluating information about religions. Otherwise the description of the task of RE focuses on individual growth and maintaining peaceful relationships between convictions. (Finnish National Agency for Education, 2016.) Thus, even if responsibility and democracy are mentioned-'the instruction of religion supports the pupil's growth into a responsible member of his or her community and the democratic society as well as a global citizen' (Finnish National Agency for Education, 2016, p. 726) — this seems directed more towards community cohesion than towards changemaking.

Interestingly, the content area 'Good life' includes 'ecosocial knowledge and ability, participation and involvement in communities and society' (Finnish National Agency for Education, 2016, p. 729). Ecosocial knowledge and ability, proposed by Salonen (see e.g. Salonen \& Konkka, 2015), suggests that a new hierarchy of ecological, social and economic aspects of well-being is needed as well as a shift from individual values to recognition of interdependence. As this concept addresses not only ecology but also social inequality, it comes quite close to informed empathy and widening the moral circle (Dolby, 2012).

Another important concept in relation to justice is participation. It appears several times in the national curriculum, especially in the underlying values and importantly in the seventh transversal competency mentioned above. In the RE curriculum it is mentioned twice, 
in the above quotation under 'Good life' and another place concerning learning processes instead of social action. It can be concluded that in the Finnish curriculum, the potential of $\mathrm{RE}$ to enhance social awareness and participation is not fully recognized.

In Finnish there are two words for participation: 'osallistuminen' refers to acts of participating; 'osallisuus' refers to the ability and opportunity to participate and sense of belonging. Although the latter in the educational discourse is often diluted to participation in any joint action in almost any role, the term has the capacity to include not only an individual's choice to participate or not but also the obligation of those in power to enable and encourage participation. 'Osallisuus' was discussed in one of the observed classroom activities. It is translated as participation in the citations but referred to as parity of participation (Fraser, 1998) in the analysis in order to use an established concept.

In a comparison of civic and citizenship education in 16 countries, Finnish eighth graders scored above average in civic knowledge. They were well able to recognize issues that are generally considered as good and bad for democracy. However, they scored below average on both conventional and social-movement-based forms of citizenship and on participation in school democracy. They were also less active than average in the forms of social participation possible for young people below voting age. (Schulz et al., 2018.) These results highlight the need to address social participation in various school subjects. Kuusisto and Kallioniemi (2014) observed that Finnish lower secondary school pupils expressed mainly neutral opinions concerning their need to learn about religion as a factor in societal questions. This lukewarm attitude may be due to the absence of those issues from the RE practice.

Critical citizenship education in RE has not been researched from the pupil or classroom perspective. In social studies education, surveys have been conducted on children's (e.g. Virta \& Virta, 2015) and young people's (e.g. Maguth \& Koskey, 2019) interests and concerns, and on the factors that contribute to citizenship preparation, although the latter proved to be difficult to define and measure (Mathé \& Elstad, 2018). According to the International Civic and Citizenship Education Study, students' social background, perception of an open classroom climate for discussion, and civic engagement at school were important predictors of civic knowledge. However, civic knowledge predicted only the students' expectation that they would vote in elections in the future, not more active forms of political involvement. Instead, expected civic engagement was predicted by students' interest in civic issues and experience with civic participation in the community or at school. (Schulz et al., 2018.)

\section{Research design: material and methods}

This study is based on classroom activities that were designed and piloted in the project. As the activities were diverse and short-term and as there were no control groups, this study does not intend to evaluate their overall efficiency. Instead, the aim of this study is to investigate qualitatively young people's thinking about social justice and its interplay with certain characteristics of the activities. The activities addressed in this study were conducted in two similar schools in privileged urban areas. Only one teacher participated in each school, and the teacher in school A was involved in the project and in the design of one of the activities. The teachers chose suitable topics from the provided alternatives, designed the details of the lessons and led the discussions. 
The five observed lessons are presented in Table 1. The classroom activities lasted from 45 to $110 \mathrm{~min}$. They were mainly conducted in Lutheran RE classes. Observation 4 was fully and observation 3 partly in a social studies class. They are included because they can be used in RE classes when social ethics is addressed and because the pupil groups in these cases were similarly homogeneous.

Observations 1, 3, and 5 were conducted by two observers, the author and a research assistant; for timetable reasons, lessons 2 and 4 were observed by the author alone. Observers wrote down as much they could by hand, and later the notes were transcribed and combined. The lessons were attended by 13-22 pupils aged 14-15, and only one pupil seemed not to be white. This homogeneity is rather usual in Finnish Lutheran RE classrooms, although more diverse pupil groups can be found in urban neighbourhoods with more diversity.

After the lessons, pupils were invited to one or two group interviews. Altogether 25 pupils (12 girls and 13 boys) participated in the eight interviews (durations circa 10-20 min). The interviews were conducted either by the author alone, together with a research assistant, or by the research assistant. The interviews were audio recorded and transcribed verbatim. For both observation and interviews, participation was voluntary for the pupils and informed consent was obtained from their parents.

Group interview was selected to reduce the power imbalance between the interviewer and the young people. It also provided the interviewees with an opportunity to build on each other's talk. (Eder \& Fingerson, 2001.) As stimuli, two sets of words were used. The words were presented printed on pieces of paper and the pupils were asked to pick those that they experienced during the activity. The words included both concepts from the project goals (e.g. caring, change) and characteristics of a meaningful (e.g. enthusiasm, idea) or non-meaningful (e.g. boredom, confusion) learning activity in general. They were intended to focus the discussion but to offer a wide choice (Table 2).

The analysis was conducted using Atlas.ti. First, the instances in the data where justice or informed empathy were involved were identified. Second, these 125 instances were subjected to qualitative content analysis (Schreier, 2012). The data analysis focused on the following questions: how do pupils understand or address justice and related concepts, empathy and information? Where is the need for justice attached (e.g. history, countries abroad, one's own life) and for which groups (e.g. cultural, gender, socioeconomic)? A single citation could answer more than one of these questions and contain several answers to a single question. The answers to the questions were coded inductively but counting them did not provide meaningful answers to the research questions. So, the codes were used as a checklist for understanding the diversity of the data. Third, excerpts representing key features of that diversity, but deepening the picture of the interplay between justice, empathy and information in the activities and pupils' views on justice issues in RE, were chosen for closer scrutiny. These excerpts were then examined for the elements of informed empathy defined above.

\section{Results}

When introducing the results, I move from the second to the first part of the concept of informed empathy, connect this to social justice literacy, and explain how pupils engage with these two concepts in school RE. 


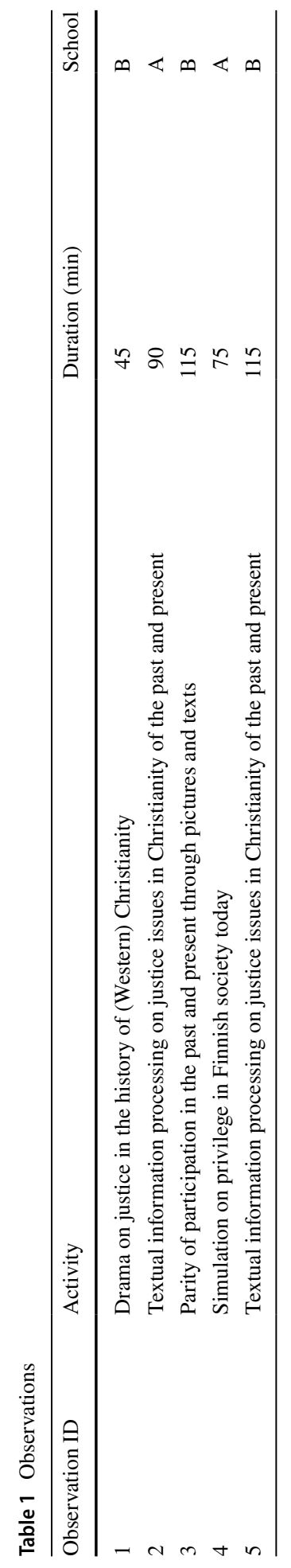


Table 2 Words used as stimuli in interviews

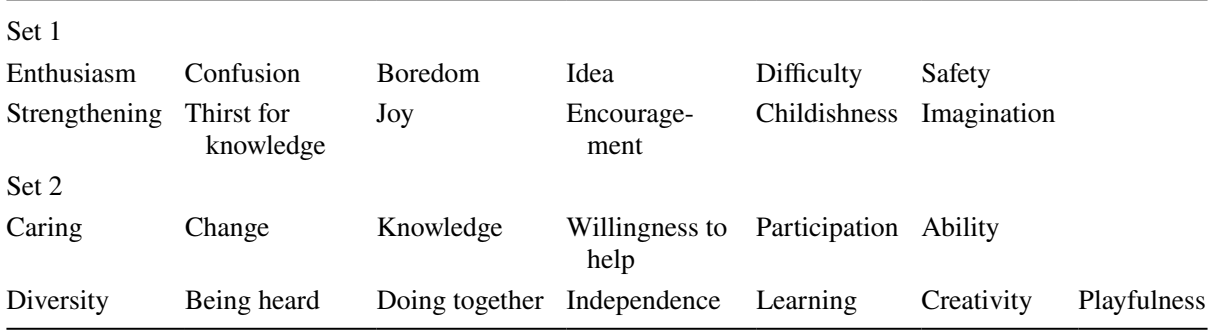

\subsection{Empathy: taking other perspectives}

In this section, I focus on taking other perspectives, or empathy, as a basis for social justice literacy. Pupils used both propositional and presentational knowing when empathizing with other perspectives, but presentational knowing helped them to empathize more.

In observation 1, drama activity was used to encourage pupils to take different perspectives, and empathize with them. Groups were assigned to prepare for improvised dialogues related to the history of Western Christianity. In the following, a group of two boys and two girls struggle with the task to prepare some lines for an early 20th-century atheist man (in Finland) who does not want to get confirmed just to get married, so he is unable to marry (civil marriage was introduced only on Finnish independence in 1917).

'We have to decide why they want to be non-Christian.' 'He prayed for the recovery of a family member but they didn't recover.' Conversation goes on from the recovery issue. I interfere and remind the group that the dialogue is about why the man does not want to get confirmed. 'He's an honest guy.' 'Maybe the man doesn't want to cause sin for the woman.' [Two pupils:] 'This is too difficult!' 'God would get mad and kill him.' 'If you don't believe, you aren't afraid of God.' 'One of his friends would probably rather kill...' 'He doesn't want to get married religiously.' [With small laugh, stressing the word married] 'Doesn't want to get married.' [Turning to me] 'Why are we doing this?' I: 'Which aims could this have?' '[Diverse] perspectives.' 'Cooperation.' 'Joy of learning.' (Observation 1.)

The pupils do not use the word empathy, but one of them recognizes that perspectivetaking could be an aim of this activity, and he returned to this in the interview afterwards. At first, the pupils find the task and setting confusing. They start using their experiential knowing about modern Finnish society, reflecting on why somebody would not believe in God, but their distance from the historical situation is so great that it does not help them. After some guidance, they go on reflecting on the beliefs of that time and social relationships relevant for the case. Power and justice issues are not prominent in this discussion.

The group was to present their lines to another group that had prepared to take the part of the bride-to-be. It turned out as follows:

'Groom' group: 'God didn't heal my mother. I don't want to join the church for economic and conscience reasons.' [...]

'Bride' group: 'We should get married so that people would accept us better.'

'Groom' group: 'But then I can't accept myself, am I not more important to you?' 
'Bride' group: 'But [our future] child may get discriminated against!' (Observation 1.)

Again, the group doing the groom-to-be's part starts from a modern standpoint, talking about joining, not leaving the church, which at that time was impossible. The other group has realized the stigma an unmarried couple and their child could face in the past, showing some critical social justice literacy. Then, one of the members of the first group realizes that the issue at stake is the freedom of conscience of the groom-to-be, also a sign of a degree of critical social justice literacy. This sudden insight may be a result of presentational knowing based on the role-taking that is now deepened by the contribution of the other group. However, no references are made to the wider societal value system or to changing it. This could take place in the debriefing with the teacher, but time runs out, and the pupils rush to lunch.

Another group had the task to empathize with Protestants of the reformation era, and they chose to be Lutherans.

'Heretics' group [reads from their notebook in turns]: 'It is the 16th century, we are Lutherans. Lutheranism is forbidden. We are accused of heresy. It's not fair that the Catholic church has arrested researchers [sic]. Selling indulgences is wrong. One gets to Heaven by grace alone. [The list of Protestant dogmas goes on.]'

'Inquisition' group [to the teacher]: 'What, we thought we had to interrogate some heretics?'

Teacher: 'You're, like, Catholics.'

'Inquisition' group [to the 'heretics']: 'Why don't you believe in the seven sacraments?'

'Heretics' group: 'They aren't in the Bible.'

'Inquisition' group: 'When have you had the time to read that much Bible? We have been interpreting [it] for a thousand years already.' (Observation 1.)

Apparently, this vignette was easier for the pupils. Having internalized the Lutheran narrative, the pupils point at the injustices of Catholic power in the era. The dominance of the Lutheran perspective is also visible in another group's confusion when at first they do not find heresy in the Lutheran group's statements. However, they change perspective surprisingly well by pointing out the millennium-long tradition of 'their' interpretation of the Bible. Both groups use propositional knowing, things they have learnt from RE lessons, but their ease in applying it is probably based on presentational knowing, the power of the Lutheran narrative. The justice perspective they employ also comes from that narrative of honest Bible-reading Protestants oppressed by the gatekeepers of the Catholic faith who stick to tradition of interpretation instead of the Bible itself.

In observation 2, the idea was to examine both the past and the present of Christianity from certain justice perspectives. The pupils had already studied the history of Western Christianity and were working in small groups. They read the internet material linked by the teacher and had to formulate a couple of justice-related questions to discuss.

Pupil 1 [suggests to the group]: 'Is it fair that Muslims are discriminated against, like this?' Pupil 2: 'You mean in Finland? Yes, I also have a friend that...' The rest of the group does not listen or ask about the example of discrimination. (Observation 2.)

Pupil 1 manages to formulate a justice-related question on the basis of the material. Pupil 2 gets excited because they can relate to the topic through the experience of a friend. However, this seems to be irrelevant for the rest of the group. They do not 
empathize with the Muslim friend they do not know and they do not find the experience useful for completing the task. In observation 5, the activity was the same as in observation 2, but no perspective-taking was observed in the classroom discussions. The activity did not effectively arouse empathy, maybe because it did not activate experiential or presentational knowledge.

In observation 3, the significance of parity of participation was discussed. The first part of this activity dived into pupils' preunderstandings about parity of participation. Each pupil chose an interesting picture from images of Finnish art printed by the teacher. Then, without defining the concept, the teacher asked small groups of pupils to choose one of their pictures that best illustrated parity of participation. One group of boys chose The Wounded Angel (1903), a symbolist painting by Hugo Simberg that depicts a bandaged girl with angel wings sitting on a stretcher and carried by two sad-faced boys.

Boy group: 'Two assumed boys carry a wounded angel.'

Teacher: 'So [participation means] taking part, helping...'.

They boys hesitate and speak very quietly.

The teacher concludes: 'So, helping and something else.'

A boy: 'A bit difficult, I don't know what participation is.'

Teacher: 'You already know, but you just have to get words.' (Observation 3.)

The pupils in this excerpt say they do not know what parity of participation means and hence express insecurity. Still, they seem to have a feeling that the Finnish word 'osallisuus' is not just about participating, but also about caring and being cared for. Possibly their choice of picture was guided by their identifying with the young characters. If so, presentational knowing, namely empathizing with boys carrying a weak creature in a painting, helped them to recognize and express what parity of participation could entail.

In observation 4, the idea was to arouse empathy through creating characters that had coincidental attributes. The number of dots on a rolled dice defined which attributes they had to pick from a list, including e.g. ethnic background and sexual orientation. In the following, two small groups are starting to discuss their characters.

Group 1: '[It's] confusing that this one is Christian although he's gay.' The group discusses possibilities: to what extent the character practices [his religion], how conservative or liberal.

Group 2: [...] Pupil 1 reads their attributes. '[It's] confusing, that they live in city centre but don't have friends.' Pupil 2 reads the results of their character. 'This one has a lot of friends although they live in the countryside - or maybe it's possible.' Pupil 1 or 3: 'Isn't it socially more close-knit in the countryside?' Together the group thinks of a disability the pupil 2's character could have [and ends up with a physical disability]. Pupil 2: 'Hopefully this one doesn't do much forest work.' The group discusses possibilities [of making a living in the countryside]. (Observation 4.)

These two similar vignettes show how the perspective-taking worked in this activity. The pupils started with mechanical thinking (city centre - a lot of people-a lot of social connections) and stereotypes (homophobic Christians and close-knit countryside communities) but the different combinations of attributes push them to use their propositional knowing and imagination to see more options. Social justice literacy appeared later in whole-class discussion with the teacher, as will be shown below.

Overall, the pupils found it challenging to take the perspectives of people in situations distant from their own. Presentational knowing (inspired by drama and simulation) both helped them to see the need for empathy and to go deeper in perspective taking. 
Interestingly, presentational knowing inspired by art also helped them to elaborate on concepts around social justice.

\subsection{Informed empathy: information and social justice concepts as tools}

This section concentrates on the 'informed' part of the concept informed empathy on which social justice literacy is based. During the observed activities, the pupils constructed their understandings of social justice and, in the interviews, we explicitly discussed the role of information. The pupils had several understandings of justice, but the following interview excerpt shows the two most important of these.

Interviewer: 'Is it [justice] anyhow connected to this activity?'

[silence for 3 seconds]

Pupil 2: 'Mm well yes. [...] [laughter] Well I can't explain it closer but at least in my view it was.'

Pupil 1: 'Well, at least it isn't just, like, to persecute people based on religion.'

Pupil 2: 'That's what I think, too.'

Pupil 1: 'And it wouldn't be just if we were, if one group member didn't participate at all, or in this work, it wouldn't be, like, just.' (Interview 1 after observation 5)

Pupil 1 brings up two very different cases of injustice. The first is perpetrated by states. The second case is from pupils' everyday lives and any pupil's responsibility. From another perspective, the latter is an example of equality of similar duties, and the former an example of the right to freedom of religion. What aroused empathy towards persecuted people in these pupils? It is not possible to trace which material they read but maybe something that fostered presentational knowing, like stories about persecuted people. Injustices in school, obviously, were familiar to them through experiential knowing. Very often, pupils defined justice as simply equality, or fairness. More detailed cases like equal division of work and freedom of religion were both mentioned elsewhere in the data.

Parity of participation was discussed thoroughly in observation 3, and pupils brought up three aspects: belonging, participation and preconditions for participation. A group of girls, similarly to the group of boys presented above, chose a painting with a young girl as the central character. It was Under the Yoke (or Burning the Brushwood, 1893) by Eero Järnefelt, a realist painting depicting people preparing a field by burning forest.

Group of girls argue for their choice: 'Young girl as the central character, a famous painting, speaks out, brings up shadows in the society.' [...] How participation is depicted: 'Shared work and suffering, the artists' pursuit of influence in society'; Definition of participation: 'taking part, influencing the surrounding life'. (Observation 3.)

In this excerpt, shared work and suffering represent belonging, but there is also a focus on participation as social action. The painting inspires such a versatile reflection on parity of participation that the group's presentational and propositional knowing are probably both being used here as a resource. As such, similar observations were made elsewhere in the data.

Information and its connection to empathy was discussed several times in the interviews.

Pupil: 'Well yes, [I still want to know more] in the way that now that I got to think about the issue, how it [refusing confirmation in the era when it was required before marriage] went, now it would be fun to know how it really, people who really are 
[sic] in this situation, how they feel, what they have thought and got to know if what we have thought is the same and whether it is, like see and hear, different angles, like perspective on the issue.' (Interview after observation 1.)

Pupil: 'Well, maybe it kind of opened my eyes a bit, that, like, how much bad things still happen based on only religion.' (Interview 2 after observation 2.)

Pupil: 'Well maybe being heard' [was involved in this lesson] because like we just wrote [in our presentation]... In a way [somebody should] make sure that everybody knows that in some country there are these religious persecutions, so that people could help. So if somebody was persecuted they should be heard.' (Interview 1 after observation 5.)

In the interview after observation 5, information is connected to willingness to help and awareness about injustices. General awareness is also highlighted in the interview after observation 2. A cycle of need for information emerges in the interviews, as was the case after observation 1: Information can make you aware of a social problem, but awareness may create willingness to know more and respect the perspective of others. All of these ideas were repeated elsewhere in the data.

The relationship between information and willingness to foster social justice was clear in the other excerpts presented in this section: pupils gained information and new perspectives that made them both empathize and understand certain social justice concepts. This is clearly in line with Dolby's (2012) idea of informed empathy, or parts of it, but agency and critical social justice literacy (i.e. understanding the structures that enable oppression) are missing from these excerpts.

\subsection{Widening the moral circle does not necessarily increase agency}

According to Dolby (2012), informed empathy contributes to fostering social justice through widening the moral circle. However, the moral circle proved complicated to define from the pupils' discussions. Although the location of the identified injustice could be defined, empathy was a different matter, let alone a sense of agency.

Interviewer: 'Did those contents arouse any willingness to help?' [the interviewees had earlier picked the card 'willingness to help' but explained it as helping group mates finalize the groupwork]

Pupil: 'Well, yes. The material told us about these, like, how like some religious minorities somewhere for instance in China, some people are maltreated there, and their religions and... So yes, I would like to help but it's a bit difficult. I can't go to China like "hey, this isn't ok".'

[laughter] (Interview 1 after observation 2.)

The teacher stays to discuss with group 2. Now the whole group participates. They discuss extra-curricular activities and elective subjects. [...]

Pupil: 'We complained about it [an issue in the choice of elective subjects] but it didn't have an influence.' (Observation 3.)

Injustices far away from Finland may arouse empathy but simultaneously a lack of agency, like in the interview after observation 2. When the pupils discussed injustices at school, they often talked about injustices which they had faced themselves, like in the excerpt from observation 3. However, pupils started to talk about issues where they did not experience parity of participation at school only after the teacher had repeatedly invited the pupils to give examples. This reluctance may have been due to their lack of agency in school in 
general, and some specific experiences like the one narrated by a pupil in the end of the excerpt. Helping peers seems to be the most evident form of action that the teenagers felt they could take. The limited scope of Finnish young people's agency at school has also been observed by Virta and Virta (2015).

Pupils recognized different groups differently. Religious freedom was the most commonly discussed justice issue due to the orientation of observations 1, 2 and 5. Observations 3 and 4, however, were broader in scope. Apart from sexual orientation discussed above, gender equality and socioeconomic equality received closer scrutiny, and there was some discussion on accessibility. In the interview after observation 4, I asked about religious rights that were not much touched on in class:

Interviewer: 'In your small group, did you discuss it [one character's religious and ethnic minority position]?'

Pupil1: 'Umm... not really but maybe the first thing that comes to my mind is that, umm, if you don't come, umm, if your culture comes from other than the Western countries it may be really different and it may be pretty difficult to adapt to this Finnish culture.' [silence 2 seconds]

Interviewer: 'And that might lead to...?'

Pupil 2: 'Social exclusion, umm, probably something like... insecurity. Maybe... in the worst case, like, well in a bad case it might lead to your job, your adult life, so.' (Interview after observation 4.)

In this excerpt there is no sign of critical social justice literacy. Here a deficit discourse dominates, and the power position of expectations to lead a 'Western' or 'Finnish' life is not challenged. Certainly, the pupils struggle to produce even this account, and later in the interview they bring up more critical perspectives, but the excerpt shows the lack of experiential knowledge about issues like this as well as lack of propositional knowledge of suitable discourses.

Hence, widening the moral circle depended on experiential, propositional and presentational knowing. Yet widening the moral circle did not guarantee construction of agency. This hindered the quest for social justice of these ethnic and religious majority pupils.

\subsection{Social justice literacy education can increase pupils' engagement in RE classes}

Social justice literacy education was a meaningful topic to study for many pupils. Although it did not make most pupils more engaged in in RE classes, it made some pupils more interested in the subject. The following two excerpts from the same interview contain almost all the approaches the pupils took to discussions of social justice in their classes:

Interviewer: 'In your view, is it [social justice] a meaningful topic to study?'.

Pupil 1: 'Of course, yes it is.'

Pupil 2: 'It is.'

Pupil 3: 'It is quite [meaningful], although not everything is just in this world but it still is quite meaningful to study [it].'

Pupil 2: 'Good to know what is right and...'

[...]

Interviewer: 'Well, how does addressing justice and stuff like this affect your motivation to study RE?'

Pupil 1: 'Well, I don't know, probably quite kind of neutrally, like...'

Pupil 2: 'Not especially.' 
Pupil 3: 'At least it's nice to have some change that you don't always only have religion's history and stuff like that. I mean that there's occasionally something else.' (Interview 2 after observation 2.)

In the beginning, the pupils state that social justice is a meaningful topic worthy of study. Pupil 3 points out that the meaningfulness is not reduced by the fact that the world is not a very just place. This shows at least a limited sense of agency: the injustices of the world do not frustrate to the point of paralysis. Pupil 2 continues this line of thought by proposing that knowledge of injustices is useful. The utterance does not prove a sense of agency but certainly a prerequisite of action. When asked about the influence of studying social justice on their motivation in RE classes, pupils 1 and 2 do not recognize any difference but pupil 3 says that addressing social justice was a welcomed change to other topics.

In one interview, all the interviewees stated that social justice topics had no influence on motivation. One participant in another interview said that she had had an overdose of hearing about parity of participation. All the rest talked about social justice issues as a change or as meaningful or interesting topics, although in very few words. The following excerpt was the most detailed response:

Pupil: 'In my view they [justice issues] are more interesting than for instance going through the history of Christianity so I could, like, more often discuss those current topics, because, or at least for me RE isn't like the most important subject and I would like to go on with those current and important topics and they could be addressed more.' (Interview 1 after observation 2.)

This interviewee states clearly that addressing justice issues would increase the relevance of RE for her. She frames them as current and important topics as opposed to the history of Christianity. This implies that she saw herself as a potential actor regarding current topics which was not the case concerning history. Although there is not an explicit reference to agency, social justice issues increased her engagement with RE. Interest was mentioned by some other interviewees and has been connected to engagement (Hidi \& Renninger, 2006).

\section{Conclusion and discussion}

The pupils described justice as equality or fundamental rights. Parity of participation was addressed in terms of belonging, participation and their prerequisites. By acknowledging these different elements, pupils showed a degree of critical social justice literacy (Sensoy \& DiAngelo, 2017): if participation of everybody and especially minoritized groups is a goal, it is important to pay attention to the prerequisites of participation and cultivating the sense of belonging. As far as empathy is concerned, the pupils were somewhat committed to understanding people in different positions, but seeing things from a perspective other than their own sometimes required a struggle. They recognized the significance of being informed about injustices, also as a motivator for action. This is an expression of the concept of informed empathy, derived from Dolby (2012) and defined drawing on Kasl and Yorks (2016) and Moore (2008) as bridging experiential worlds through different types of knowing, critical social justice literacy and critical agency.

The observations of classroom activities showed the importance of experiential and presentational knowing. When pupils were asked to use their imaginations, they first resorted to stereotypes and discourses from their everyday life. Narratives, drama and visual arts helped them to take different perspectives and elaborate on concepts. In 
contrast, when the focus was on producing nonfiction, their ability to do so was more limited. Critical social justice literacy appeared in some of the excerpts. Sometimes it was inspired by presentational knowing, and sometimes by propositional knowing (like readings where concepts such as accessibility were introduced), alone or in combination.

Although the research described here does not fulfil the requirements of a systematic teaching method evaluation, the results support observations made by Kasl and Yorks (2016) that presentational knowing enables empathy between groups. From the point of view of informed empathy, although experiential and presentational knowing are needed to arouse interest and care, propositional knowing and critical social justice literacy are needed to achieve empathic accuracy. That is, if presentational knowing does not entail explicit descriptions, perspective-taking may be misled by stereotypes and unrecognized privilege. Propositional knowing about social justice concepts and perspectives may add to the repertoire of interpretations and discourses needed for informed empathy as a prerequisite to social justice action.

The analysis of the pupils' moral circles (Dolby, 2012), in other words, the groups and contexts their empathy reached, led to the conclusion that critical agency (Moore, 2008 ) is important. The pupils were equally interested in injustice in countries far away and at school, but in most cases they did not feel themselves capable of action-and this lack of agency also freed them from obligation to act. This observation is in line with the research finding that there is no relationship between civic knowledge and civic participation apart from voting (Schulz et al., 2018). A lack of agency may also explain this gap: mere knowledge does not produce agency.

Agency or seeing oneself at least as a potential actor is connected to the pupils' motivation to engage with social justice education in RE classes. The interviewees were from schools in privileged areas, and as volunteers for the research they probably were more prepared than average to articulate their feelings and thoughts. For these pupils, addressing social justice issues increased the relevance of RE, at least compared to some other topics such as church history. This may be due to identification or sense of belonging. Pupils in secularized societies may not feel very committed to the contents of RE as they consider themselves outside religious traditions (Sjöborg, 2013; von Brömssen, 2016). But everybody is part of a society, thus everybody is invited to critically review the relationship between religious communities and their society, and everybody can act in recognition of the diversity of worldviews in that society. This potential of RE should be further investigated.

It is important to note that the participants here mostly represented the ethnic and religious majority. Their dominant position in the larger society at least in these two respects partly explains why they struggled to take different perspectives and why they felt they learnt something new when inequalities were addressed. The concept of informed empathy is well suited for the education and research of privileged pupils, but more research is needed on concepts that help educators to address justice issues with non-privileged pupils—also in RE classrooms.

Funding Open Access funding provided by University of Helsinki including Helsinki University Central Hospital. The research was conducted within a project funded by the Finnish National Agency for Education.

Data availability No.

Code availability Not applicable. 


\section{Declarations}

\section{Conflict of interest None.}

Open Access This article is licensed under a Creative Commons Attribution 4.0 International License, which permits use, sharing, adaptation, distribution and reproduction in any medium or format, as long as you give appropriate credit to the original author(s) and the source, provide a link to the Creative Commons licence, and indicate if changes were made. The images or other third party material in this article are included in the article's Creative Commons licence, unless indicated otherwise in a credit line to the material. If material is not included in the article's Creative Commons licence and your intended use is not permitted by statutory regulation or exceeds the permitted use, you will need to obtain permission directly from the copyright holder. To view a copy of this licence, visit http://creativecommons.org/licenses/by/4.0/.

\section{References}

Arthur, J., Gearon, L., \& Sears, A. (2010). Education, politics, and religion: Reconciling the civil and the sacred in education. Routledge.

Bell, L. A. (2007). Theoretical foundations for social justice education. In M. Adams, L. A. Bell, \& P. Griffin (Eds.), Teaching for diversity and social justice (pp. 1-14). Routledge/Taylor \& Francis Group.

Boyles, D., Carusi, T., \& Attick, D. (2008). Historical and critical interpretations of social justice. In D. Stovall, W. Ayers, \& T. M. Quinn (Eds.), Handbook of social justice in education (pp. 30-42). Taylor and Francis.

Davis, M. H. (2009). Empathy. In S. Sprecher, \& H. T. Reis (Eds.), Encyclopedia of human relationships. SAGE.

Dolby, N. (2012). Rethinking multicultural education for the next generation: The new empathy and social justice. Routledge.

Eder, D., \& Fingerson, L. (2001). Interviewing children and adolescents. In F. Gubrium \& J. A. Holstein (Eds.), Handbook of interview research (pp. 181-202). Sage Publications.

Finnish National Agency for Education. (2016). National Core Curriculum for Basic Education 2014. Finnish National Agency for Education.

Francis, D., \& LeRoux, A. (2011). Teaching for social justice education: The intersection between identity, critical agency, and social justice education. South African Journal of Education, 31(3), 299-311.

Fraser, N. (1998). Social justice in the age of identity politics: Redistribution, recognition, participation. Discussion Papers, Research Unit: Organization and Employment FS I 98-108, WZB Berlin Social Science Center. https://ideas.repec.org/p/zbw/wzboem/fsi98108.html.

Gorski, P. (2012). Equity and social justice from the inside-out: Ten commitments for intercultural educators. In N. Palaiologou \& G. Dietz (Eds.), Mapping the broad field of multicultural and intercultural education worldwide: Towards the development of a new citizen (pp. 388-401). Cambridge Scholars Publisher.

Gorski, P., \& Parekh, G. (2020). Supporting critical multicultural teacher educators: Transformative teaching, social justice education, and perceptions of institutional support. Intercultural Education, 31(3), 265-285. https://doi.org/10.1080/14675986.2020.1728497

Heron, J., \& Reason, P. (2008). Extending epistemology within a co-operative inquiry. In P. Reason \& H. Bradbury (Eds.), The SAGE handbook of action research (pp. 366-380). SAGE Publications.

Hidi, S., \& Renninger, K. A. (2006). The four-phase model of interest development. Educational Psychologist, 41(2), 111-127. https://doi.org/10.1207/s15326985ep4102_4

Jackson, R. (2003). Citizenship, religious and cultural diversity and education. In R. Jackson (Ed.), International perspectives on citizenship, education and religious diversity (pp. 1-25). RoutledgeFalmer.

Jones, T. M. (2009). Framing the framework: Discourses in Australia's national values education policy. Educational Research for Policy and Practice, 8(1), 35-57. https://doi.org/10.1007/s10671-008-9058-x

Kasl, E., \& Yorks, L. (2016). Do I really know you? Do you really know me? Empathy amid diversity in differing learning contexts. Adult Education Quarterly, 66(1), 3-20.

Kimanen, A., \& Kallioniemi, A. (2018). Towards interpretive and empathetic encounters between worldviews. Nordidactica, 4, 118-135.

Kuusisto, A., \& Kallioniemi, A. (2014). Pupils' views of religious education in a pluralistic educational context. Journal of Beliefs \& Values, 35(2), 155-164. https://doi.org/10.1080/13617672.2014.953296 
Maguth, B. M., \& Koskey, K. L. K. (2019). Preparing urban youth to live-up to their civic Promise? Evaluating youth positionality of civic engagement using an arts-based instrument. Journal of Social Studies Education Research, 10(1), 1-37.

Mathé, N. E. H., \& Elstad, E. (2018). Students' perceptions of citizenship preparation in social studies: The role of instruction and students' interests. Journal of Social Science Education, 17(3), 75-87. https:// doi.org/10.4119/UNIBI/jsse-v0-i0-1779

May, S., \& Sleeter, C. E. (Eds.). (2010). Critical multiculturalism: Theory and praxis. Routledge.

Miedema, S., \& Bertram-Troost, G. (2008). Democratic citizenship and religious education: challenges and perspectives for schools in the Netherlands. British Journal of Religious Education, 30(2), 123-132. https://doi.org/10.1080/01416200701830970

Mikander, P., Zilliacus, H., \& Holm, G. (2018). Intercultural education in transition: Nordic perspectives. Education Inquiry. https://doi.org/10.1080/20004508.2018.1433432

Moore, F. M. (2008). Agency, identity, and social justice education: Preservice teachers' thoughts on becoming agents of change in urban elementary science classrooms. Research in Science Education, 38, 589. https://doi.org/10.1007/s11165-007-9065-6

Osbeck, C., Franck, O., Lilja, A., \& Sporre, K. (2018). Possible competences to be aimed at in ethics education: Ethical competences highlighted in educational research journals. Journal of Beliefs and Values, 39(2), 195-208. https://doi.org/10.1080/13617672.2018.1450807

Poulter, S. (2019). Religious education as a means of citizenship education in Finland. In M. Ubani, I. Rissanen, \& S. Poulter (Eds.), Contextualising dialogue, secularisation and pluralism: Religion in finnish public education (pp. 39-56). Waxmann.

Salonen, A. O., \& Konkka, J. (2015). An ecosocial approach to well-being: A solution to the wicked problems in the era of anthropocene. Foro De Educación, 13(19), 19-34. https://doi.org/10.14516/fde. 2015.013.019.002

Schreier, M. (2012). Qualitative content analysis in practice. SAGE.

Schulz, W., Ainley, J., Fraillon, J., Losito, B., Agrusti, G., \& Friedman, T. (2018). Becoming citizens in a changing world IEA international civic and citizenship education study 2016 international report. Springer. https://doi.org/10.1007/978-3-319-73963-2

Sensoy, O., \& DiAngelo, R. (2017). Is everyone really equal?: An introduction to key concepts in social justice education. Teachers College Press.

Sjöborg, A. (2013). Religious education and intercultural understanding: Examining the role of religiosity for upper secondary students' attitudes towards RE. British Journal of Religious Education, 35(1), 36-54. https://doi.org/10.1080/01416200.2012.717015

Sleeter, C. E. (1996). Multicultural education as social activism. State University of New York Press.

Virta, A., \& Virta, M. (2015). What to change-How to have influence? Children's ideas about exercising power and participating. Journal of Social Science Education, 14(2), 81-91. https://doi.org/10.2390/ jsse-v14-i2-1296

von Brömssen, K. (2016). Some ethnic Swedish students' discourses on religion: Secularism par excellence. Journal of Religious Education, 64(2), 113-125. https://doi.org/10.1007/s40839-3017-0036-6

Publisher's Note Springer Nature remains neutral with regard to jurisdictional claims in published maps and institutional affiliations. 